\title{
Antimicrobial susceptibility of clinical isolates of Pseudomonas aeruginosa for Mansoura area.
}

Ashraf A. Kadry, Fathy M. Serry, Ahmed M. El-Baz*

Department of Microbiology and Immunology-Faculty of Pharmacy-Zagazig UniversityZagazig Egypt

*Corresponding Author E-mail: Elbaz_pharmacy@yahoo.com

\begin{abstract}
The aim of the present study was to determine both susceptibility and resistance pattern among clinical isolates of Pseudomonas aeruginosa in order to make continuous monitoring to the action of antipseudomonal drug in Egypt and to initiate the treatment with the appropriate antibiotic to avoid failure of treatment due to resistance. A total of 104 clinical isolates were collected and identified as Pseudomonas aeruginosa from Mansoura University Hospitals. The isolates were tested for antimicrobial susceptibility against 10 different antibiotics by using disk diffusion method. Resistance rates for imipenem, piperacillin, amikacin, gentamicin and ciprofloxacin were found 19.23\%, 20.19\%, 24\%, 26.92\%, and 30.76\%; respectively. Resistance rates to chloramphenicol, co-trimoxazole, ceftazidime and ceftriaxone were variable and reached up to $83.65 \%$. Exceptionally all isolates were resistant to carbencillin (100\%). Thirty-six (34.61\%) of isolates were multi-drug resistant. Imipenem, piperacillin and amikacin were the most effective antimicrobial agents against Ps. aeruginosa clinical isolates. It is recommended by the health authority to limit the further increase of antimicrobial resistance among Ps. aeruginosa by declining the rational treatment regimen.
\end{abstract}

Key words: Susceptibility, Disk method, Pseudomonas aeruginosa, Antimicrobial, Multidrug resistant.

\section{INTRODUCTION}

Continuous survey for susceptibility pattern of Pseudomonas aeruginosa in Egypt geographical area is important to grade the antibiotic therapy and for developing resistance control. The present study aimed to determine the antibiotic susceptibility profile in level variable by Hospitals of Mansoura University.

Pseudomonas aeruginosa is a notorious opportunistic pathogen and is isolated mostly from patient with urinary tract infections, wound infections, and severe burns. Ps.aeruginosa has been considered a nosocomial pathogen in a number of studies. Ps.aeruginosa infections are also known to be a serious problem in hospitalized patients with cystic fibrosis, cancer and burns. Half of these infections are fatal. Those infections are problematic due to the bacterial resistance to antibiotic and disinfectants (Lambert, 2002).
Proliferation and transmission of antimicrobial-resistant bacteria is accelerated by close contact between individuals in institutions such as hospitals, day care centers and military barracks (Goldmann, 1999). The mobility of the world's populations also facilitates the rapid dissemination of microorganisms harboring antibiotic resistance genes (Goldmann, 1999). The spread of antibiotic resistance within a hospital, country or globally is usually achieved by clones with a high transmission ability (Livermore, 2003).

The evolution and spread of antibiotic resistance in bacteria is a complex process involving a variety of different mechanisms. Some bacterial species show a high intrinsic resistance to specific antibiotics, while susceptible bacteria may acquire resistance by alterations in their own genome via mutations or the transfer of resistance genes 
located on mobile DNA elements (Normark and Normark, 2002).

Pseudomonas aeruginosa show intrinsic and acquired resistance to many structurally unrelated antibiotics, and extensive use of antibiotics often leads to multidrug resistant Pseudomonas aeruginosa strains (Toscano et al., 1991; Ciofu et al., 1994).

\section{MATERIAL and METHODS Bacterial isolates}

One hundred and four non duplicate Ps. aeruginosa isolates were collected from Mansoura University hospitals, from different clinical samples (wound swab, burn swab, ear swab, endotracheal swab and urine), identified and verified by using the standard biochemical reactions according to Collee et al. (1996). All isolates were collected under approved ethical procedures.

Antimicrobial Susceptibility testing

The susceptibility was determined by disk diffusion method according to CLSI (2006) on Muller-Hinton agar (Oxoid UK). The susceptibility against the clinical isolates testing was performed against 10 antimicrobial agents belonging to 5 different groups: Ceftriaxone (CRO, 30 $\mu \mathrm{g}$ ), Piperacillin (PRL, 100 $\mu$ g), Carbenicillin (CAR, 100 $\mu \mathrm{g}$ ), Ceftazidime (CAZ, 30 $\mu \mathrm{g}$ ),

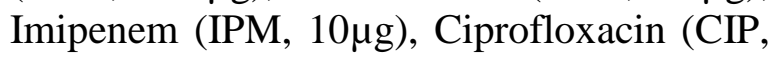

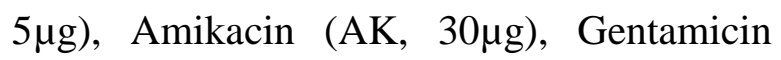
(CN, $\quad 10 \mu \mathrm{g}), \quad$ Sulfamethoxazole /Trimethoprime (SXT, 23.27/1.25 $\mu \mathrm{g}$ ), Chloramphenicol (C, 30 $\mu \mathrm{g})$. The antibiotics disks were obtained from Oxoid, Hampshire, England. The results were interpreted according to the criteria indicated in CLSI (2006) guideline.

\section{RESULTS}

\section{Susceptibility patterns of Ps. aeruginosa to different antibiotics}

Antimicrobial susceptibility pattern of Pseudomonas aeruginosa were varied markedly with the antibiotic tested. Highest resistance rates were found to carbencillin (100\%) and the least resistance were found to imipenem (19.23\%). The resistance pattern of Ps. aeruginosa to various antibiotics tested was in the following descending order: carbencillin $(100 \%)$, ceftriaxone $(83.65 \%)$, ceftazidime $(69.23 \%)$ sulfamethoxazole/trimethoprime $\quad(56.73 \%)$, chloramphenicol (38.46\%), ciprofloxacin $(30.76 \%)$, gentamicin $(26.92 \%)$, amikacin (24\%), piperacillin $(20.19 \%)$ and imipenem (19.23\%) as shown in Table (1) and Figure (1-2). Multi-drug resistance (resistance to 3 or more different families of antibiotics tested) was found in 36 isolates (34.61\%) of Ps. aeruginosa tested (Table 2).

Table (1): Susceptibility patterns of Pseudomonas aeruginosa to different antibiotics.

\begin{tabular}{|c|c|c|c|c|c|c|}
\hline \multirow[t]{3}{*}{ Antibiotic Disk } & \multicolumn{6}{|c|}{ Pseudomonas $\operatorname{spp}(\mathrm{n}=104)$} \\
\hline & \multicolumn{2}{|c|}{$\mathrm{R}$} & \multicolumn{2}{|c|}{$\mathrm{I}$} & \multicolumn{2}{|c|}{$\mathrm{S}$} \\
\hline & $\mathrm{N}$ & $\%$ & $\mathrm{~N}$ & $\%$ & $\mathrm{~N}$ & $\%$ \\
\hline PRL & 21 & 20.19 & 0 & 0 & 83 & 79.8 \\
\hline IPM & 20 & 19.23 & 2 & 1.93 & 82 & 78.84 \\
\hline CAZ & 72 & 69.23 & 18 & 17.3 & 14 & 13.46 \\
\hline $\mathrm{CRO}$ & 87 & 83.65 & 3 & 2.88 & 14 & 13.46 \\
\hline CAR & 104 & 100 & 0 & 0 & 0 & 0 \\
\hline AK & 25 & 24 & 3 & 2.88 & 76 & 73 \\
\hline $\mathrm{CN}$ & 28 & 26.92 & 4 & 3.84 & 72 & 69.23 \\
\hline CIP & 32 & 30.76 & 7 & 6.73 & 65 & 62.5 \\
\hline C30 & 40 & 38.46 & 21 & 20.19 & 43 & 41.34 \\
\hline SXT & 59 & 56.73 & 32 & 30.76 & 13 & 12.5 \\
\hline
\end{tabular}


Table (2): Numerical antimicrobial resistance patterns of Pseudomonas aeruginosa clinical isolates.

\begin{tabular}{lcc}
\hline No of groups of antibiotics & No of Ps. aeruginosa isolates & $\%$ of Ps. aeruginosa isolates \\
\hline Resistance $<3$ groups & 68 & $65.38 \%$ \\
Resistance $=3$ groups & 1 & $0.96 \%$ \\
Resistance $=4$ groups & 16 & $15.38 \%$ \\
Resistance $=5$ groups & 19 & $18.26 \%$ \\
\hline
\end{tabular}

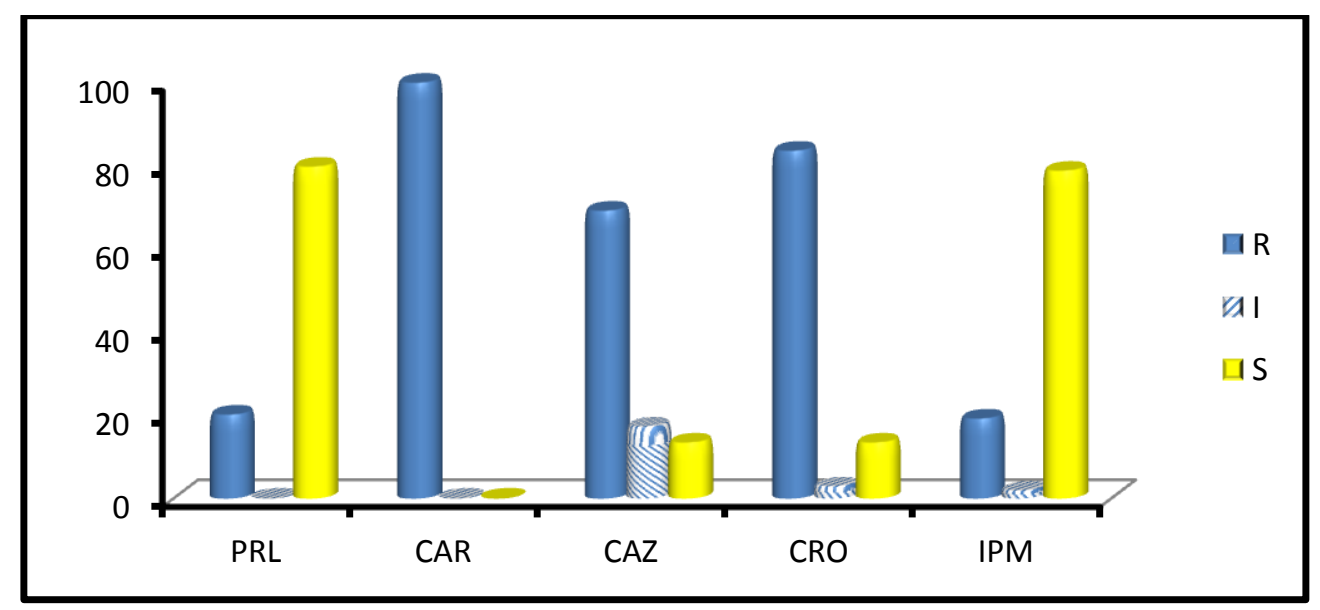

Figure (1): Susceptibility of Pseudomonas aeruginosa toß-Lactam (Subclass Penicillins), used Piperacillin (PRL) and Carbencillin (CAR), (Subclass Cephalosporins), used Ceftazidime (CAZ) and Ceftriaxone (CRO), (Subclass Carbapenem), used Imipenem (IPM).

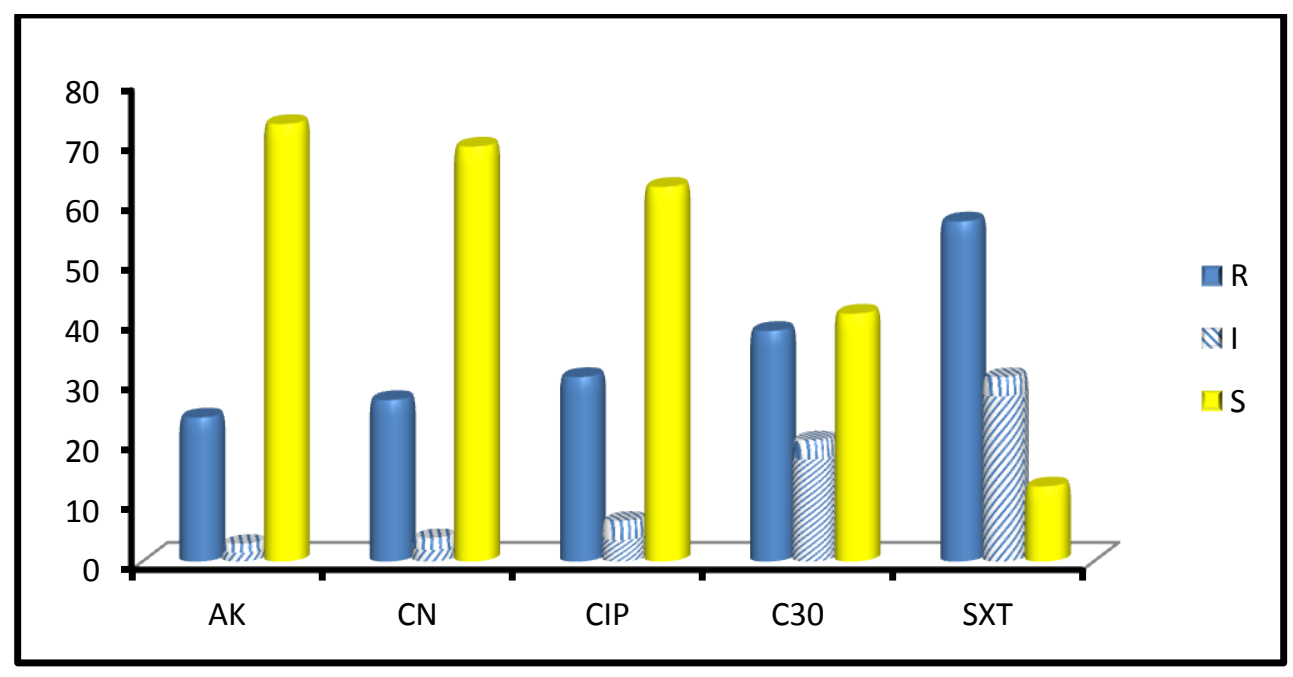

Figure (2): Susceptibility of Pseudomonas aeruginosa to Quinolone used Ciprofloxacin (CIP), Aminoglycosides used Amikacin (AK) and Gentamicin (CN), Chloramphenicol $\left(\mathrm{C}_{30}\right)$, Suphamethoxazole trimethoprime (SXT).

\section{DISCUSSION}

Among the 104 Pseudomonas aeruginosa isolates collected, thirty six
$(34.61 \%)$ were showed multidrug resistance while other study revealed that $(20.69 \%)$ reported in Nepal by Chander et al. (2013), 
while other study revealed that (19.6\%) reported in Malaysia by Pathmanathan et al. (2009). From these MDR isolates only one (2.77\%) isolate was resistant to 3 groups of antimicrobial agents, sixteen (44.44\%) isolates were resistant to 4 groups of antimicrobial agents and nineteen $(52.77 \%)$ isolates were resistant to 5 groups of antimicrobial agents (Table 2).

In the present study about $19.23 \%$ of Ps.aeruginosa isolates were resistant to imipenem (IPM) which was less than 39.34\% and $41.4 \%$ reported in Egypt by Zafer et al. (2014) and Afifi et al. (2013), respectively. One study in the world was in complete agreement with the present study reported by Bonfiglio et al. (19.3\%) in 1998, and other studies gave comparable results in the range between $14 \%$ and $26.1 \%$ reported by (Bouza et al, 1999; Fatima et al, 2012; and Akhtar, 2010); respectively.

Our investigation also showed about $20.19 \%$ of Ps.aeruginosa isolates were resistant to piperacillin (PRL) which was diverted with that reported by Al-Tawfiq (2007) and Shenoy et al. (2002) where $11.5 \%$ and $54.66 \%$ of the isolates, respectively were resistant to piperacillin.

In the present study about $69.23 \%$ of Ps.aeruginosa isolates were resistant to ceftazidime (CAZ) which in agreement with Zafer et al. 2014 in Egypt which reported the resistance $60.6 \%$ and disagreement with that reported by Afifi et al. (2013) in Egypt where $19.5 \%$ of the isolates were resistant.

In the present study, the clinical isolates show high resistance against ceftriaxone, where $83.65 \%$ of isolates were resistant. This high resistance was in agreement with that reported by Afifi et al. (2013), Rashid et al. (2007) and Bhandari et al. (2012) where $78.1 \%, 86 \%$ and $93.9 \%$ of the isolates were resistant.

In the present study, $24 \%$ of Ps.aeruginosa isolates were resistant to amikacin (AK), which was in agreement with that reported by Zafer et al. 2014 (32.8\%), where $7.8 \%$ of the isolates were reported resistant by Afifi et al.(2013). High resistance was expressed by the same organisms in studies performed by Viren $e t$ al.(2008), and Sivanmanliappan \& Sevanan (2011) where $48.2 \%$ and $33.4 \%$ were susceptible; respectively.

In the present study about $26.92 \%$ of Ps.aeruginosa isolates were resistant to gentamicin $(\mathrm{CN})$ which in agreed with that reported by Afifi et al. 2013 (21.1\%). This resistance was less than that reported by Zafer et al. 2014 and Viren et al. (2008) where $50 \%$ and $67.86 \%$ of the isolates were resistant; respectively. High resistance was expressed by the Ps.aeruginosa in study carried by Updhaya et al. (2014) where $47.1 \%$ of resistance were recorded.

According to Gales et al. (2001), ciprofloxacin was reported as one of the most potent drug. As shown in Table (1) and Figure (2), this investigation revealed that $30.76 \%$ of the isolates were resistant to ciprofloxacin, this result was consistent with that reported by Zafer et al. 2014 (43.4\%), Amadi et al. 2008 (25.5\%), Updhaya et al. 2014 (35.5\%) and Brown et al. 2004 $(23.5 \%)$, respectively.

In the present study about $38.46 \%$ of Ps.aeruginosa isolates were resistant to chloramphenicol (C30). This resistance was less than that reported by Amadi et al. 2008 (58.8\%) and Viren et al. 2008 (75\%).

In the current study about $56.73 \%$ of $P$ s. aeruginosa isolates were resistant to sulphamethoxazol/trimethoprim(SXT) which is consistent with that reported by Brown et al.(2004) and Chander et al.(2013), where $56.9 \%$ and $51.72 \%$ of the isolates were resistant; respectively.The data revelead that imipenem, piperacillin, amikacin, gentamicin, and ciprofloxacin are considered the best options in treatment of Ps.aeruginosa. Other antimicrobial agent under investigationwere not encouraged to be 
considered in the treatment of Ps.aeruginosa infections (Chander et al., 2013; Brown et al., 2004 and Fatima et al. 2012). In conclusion, results of the present study revealed the distributions of the resistance to various antipseudomonal drugs among the Ps.aeruginosa isolates. Imipenem and piperacillin are still the best as antipseudomonal drugs. Aminoglycosides (amikacin and gentamicin) and ciprofloxacin have good activity against the Ps.aeruginosa isolates. Periodic monitoring of the antimicrobial has great importance in order to help the medical team to prescribe the optimal antipseudomonal agents and rule out the ineffective ones from the regimen therapy as well as the avoidance of emerging of multi-drug resistant strains of Ps.aeruginosa.

\section{REFERENCES}

1. Afifi, M. M.; Suelam, I. I.; Soliman, M. T.; and El-Gohary, M. G. (2013). Prevalence and antimicrobial susceptibility pattern of Pseudomonas aeruginosa isolated from environmental and clinical samples in Upper Egypt. Int. J. Biol. Chem., 7(2): 47-57.

2. Al-Twafiq, J. A. (2007). Occurrence and antimicrobial pattern of inpatient and outpatient isolates of Pseudomonas aeruginosa in a saudi Arabian hospital: 1998-2003. Int. J Infect. Dis. 11: 109-14.

3. Akhtar, N. (2010). Hospital acquired infections in a medical intensive care unit. J Coll. Physicians. Surg. Pak. 20(6):386-390.

4. Amadi, E.; Uzoaru, P.; Orji, I.; Nwaziri, A.; Iroha, I. (2008). Antibiotic resistance in clinical isolates of Pseudomonas aeruginosa in Engu and Abakaliki, Nigeria. The Internet Journal of Infectious Diseases Vol 7(1).

5. Bhandari, S.; Banjara, M. R.; Lekhak, B.; Bhatta, D. R.; Regmi, S. R. (2012). Multi-drug and Pan-drug Pseudomonas aeruginosa : a challenge in post antibiotic era. Nepal. J. Sci. Tech. 13(2):197-202.

6. Bonfiglio $\mathrm{G}$, Carciotto V, Russo $\mathrm{G}$ (1998). Antibiotic resistance in Pseudomonas aeruginosa : an Italian survey. Antimicrob Chemother 41: 307310.

7. Bouza, E.; Garcia-Gorrote, F.; Cercenado, E.; Marin, M.; Diaz M., S. (1999). Pseudomonas aeruginosa a survey of resistance in 136 hospitals in Spain. The Spanish Pseudomonas aeruginosa study group antimicrob agents chemother, $43^{\text {rd }}$ edn, pp 981-982.

8. Brown, P., D.; and Izundu, A. (2004). Antibiotic resistance in clinical isolates of Pseudomonas aeruginosa in Jamaica. Rev. Panam. Salud. Publica., 16 (2):12530.

9. Chander, A.; Raza, M., S. (2013). Antimicrobial susceptibility patterns of Pseudomonas aeruginosa clinical isolates at a tertiary care hospital in Kathmandu, Nepal. Asian. J. Pharm. Clin. Res. 6(3): 235-238.

10. Ciofu, O.; Giwercman, B.; Pedersen, S. S.; Hoiby, N. (1994). Development of antibiotic resistance in Pseudomonas aeruginosa during two decades of antipseudomonal treatment at the Danish CF center. APMIS, 102(9):674-80.

11. Clinical and laboratory standards institute (CLSI) (2006). Performance standards for antimicrobial disk susceptibility tests. Approved standards. In Ninth edition document M2-A9. Clinical and laboratory standards Institute, Wayne, PA.

12. Collee, J. G.; Miles, R. S.; Watt, B. (1996). Tests for the identification of bacteria. $14^{\text {th }}$ edition. Churchill livingstone, New York.

13. Fatima, A.; Naqvi, S. B.; Khaliq, S. A.; Perveen, S.; Jabeen, S. (2012). Antimicrobial susceptibility pattern of clinical isolates of Pseudomonas 
aeruginosa isolated from patients of lower respiratory tract infections. $J$ SpringerOpen, 1: 70.

14. Gales, A.C. ;Jones, R.N.; Turnidge, J. et al., (2001). Characterization of Pseudomonas aeruginosa: occurrence rate, antimicrobial susceptibility pattern and molecular typing in the global sentry antimicrobial surveillance program 19971999. Clinic. Infect. Dis. 32 :S146-155.

15. Goldmann, D. A. (1999). The epidemiology of antimicrobial resistance. Ecosys. Health, 5: 158-163.

16. Lambert, P.A. (2002). Mechanisms of antibiotic resistance in Pseudomonas aeruginosa. J R Soc Med. 95 Suppl 41: 22-26.

17. Livermore, DM. (2003). Bacterial resistance: origins, epidemiology, and impact. Clin. Infect. Dis, 36: 11-23.

18. Normark, H. B.; and Normark, S. (2002). Evolution and spread of antibiotic resistance. J. Intern. Med., 252: 91-106.

19. Pathmanathan, S. G.; Samat, N. A.; Mohamed, R. (2009). Antimicrobial susceptibility of clinical isolates of Pseudomonas aeruginosa from a Malaysian hospital. Malays J Med Sci, 16(2):27-32.

20. Rashid, A.; Chowduhry, A.; Rahman, S. H.; Begum, S. A.; Muazzum, N. (2007). Infections by Pseudomonas aeruginosa and antibiotic resistance pattern of the isolates from Dhaka Medical College Hospital. Bangladesh J Med Microbiol 1(2): 48-51.

21. Shenoy, S.; Baliga, S.; Saldanha D. R. ; Prashanth, H. V. (2002). Antibiotic sensitivity patterns of Pseudomonas aeruginosa strains isolated from various clinical specimens. Indian. J Pharmacol., 40(5): 230-34.

22. Siva, G. P.; Nor, A. S; Ramelah, M. (2009): Antimicrobial Susceptibility of clinical isolates of Pseudomonas aeruginosa from a Malaysian hospital. $M J M S, 16(2): 28-33$.

23. Sivanmalippan T.S. and Sevanan M. (2011): Antimicrobial susceptibility patterns of Pseudomonas aeruginosa from diabetes Patients with foot ulcer. Int. J. of Microbiol, 2011:605195.

24. Toscano, M. A.; Minneci, M.; Salmeri, M.; Nicoletti, G. (1991). New epidemiological data on resistance to netilmicin and other aminoglycosides. $J$ Chemother, 3(6): 352-6.

25. Updhaya, S.; Shenoy, R.; Shetty, V.; Lamasal, A.; Lamichhane, P.; Pokhrel, S. (2014). Multidrug resistant Pseudomonas aeruginosa isolated from intensive care burn unit. IJBR. 5 (4):271-273.

26. Viren, A. J.; Somsuvra, B. G.; Kamlesh, R. P. (2008). Antibiotic susceptibility patterns of Pseudomonas aeruginosa at a tertiary care hospital in Gujarat, India. Indian J Pharmacol. 40(5): 230-234.

27. Zafer, M. M.; Al-Agamy, M. H.; ElMahallawy, H. A.; Amin, M. A.; and and Ashour, M. S. (2014): Antimicrobial resistance pattern and their betalactamase encoding genes among Pseudomonas aeruginosa strains isolated from cancer patients.

Biomed.Res.Int.2014:101635. 


\section{تعيين حساسية العزلات السريرية لميكروب السودوموناس ايروجينوزا ضد المضادات الحيوية في المنطقة المحيطة لمدينة المنصورة المورئوز}

\section{أشرف أحمد قدري، فتحي حمحل سري، أحمد كحمة الباز

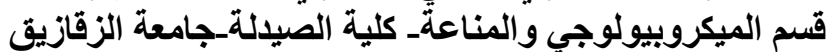

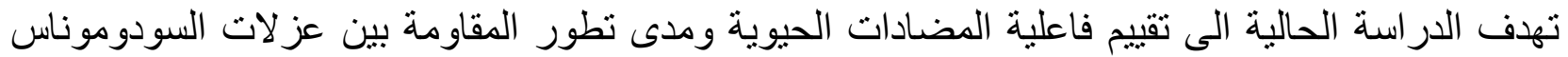

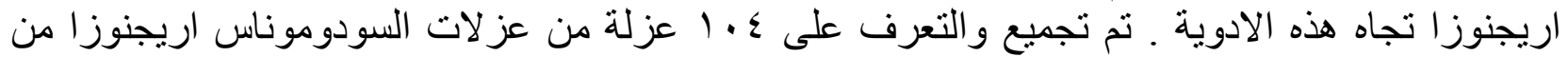

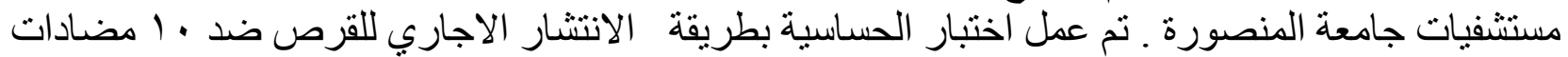
حيوية مختلفة.

أوضحت النتائج وجود مقاومة عالية من عزلات لات السودوموناس اريجنوزا تجاه كل من الكاربنسللين

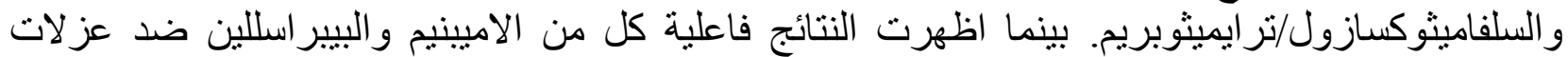

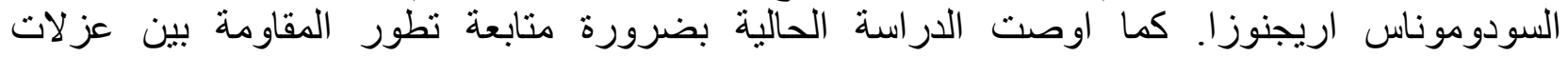

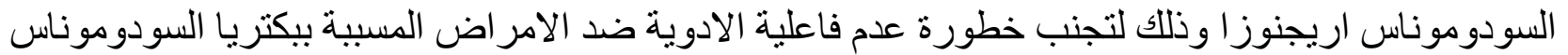
اريجنوزا. 